\title{
Breast milk zinc and copper concentrations in Bangladesh
}

\author{
BY KAREN SIMMER \\ Department of Paediatrics, Flinders Medical Centre, Bedford Park, South Australia 5042, Australia \\ AND SHAMEEN AHMED \\ International Centre for Control of Diarrhoeal Diseases, Dhaka, Bangladesh \\ AND LINDA CARLSSON AND R. P. H. THOMPSON \\ Gastrointestinal Laboratory, St Thomas's Hospital, London SE1 7EH
}

(Received 1 February 1989 - Accepted 10 August 1989)

\begin{abstract}
Breast-fed infants in Bangladeshi villages were weighed at 1, 2, 6,9 and 12 months. The concentrations of zinc and copper in the breast milk were measured and the daily intake of these elements calculated. Breast milk Zn concentration decreased over the year but was comparable with that found in developed countries. The calculated daily intake decreased from 17.7 to $8.0 \mu \mathrm{mol}(10-30 \%$ of recommended dietary allowances (RDA); National Academy of Sciences, 1980). Breast milk Cu concentration also fell over the year and was lower than that reported from developed countries. Calculated daily $\mathrm{Cu}$ intake was 1.95-2.63 $\mu \mathrm{mol}$ (RDA 7.81-15.63 $\mu \mathrm{mol}$ ). Deficiencies of trace elements may therefore be a problem in poorly nourished communities where breast feeding is continued for several years with only small amounts of additional food. Breast milk may not be adequate as the only source of infant nutrition after the first few months of life in Bangladesh.
\end{abstract}

Breast milk: Copper: Zinc

Unsupplemented human milk is all that is required to maintain growth in the first 6 months of life in infants of well-nourished mothers. Breast milk of poorly nourished mothers, although surprisingly good, is often suboptimal in quantity and quality. The volume produced is smaller, and the concentrations of fat, water-soluble vitamins, vitamin $A$, calcium and protein are lower than in breast milk from well-nourished women (Jelliffe \& Jelliffe, 1978).

Little is known of the breast milk concentrations of essential trace elements in developing countries. Deficiencies of zinc and copper may occur in communities where breast-feeding is continued for several years with only small amounts of additional food, and such deficiencies may limit the rate of weight gain (Golden \& Golden, 1981 ; Simmer et al. 1988) and accentuate the anaemia, bone disease and susceptibility to infection (Al-Rashid \& Spangler, 1971; Levy et al. 1985; Sutton et al. 1985) which occur in malnourished children. We therefore measured $\mathrm{Zn}$ and $\mathrm{Cu}$ concentrations of breast milk in Bangladesh and discuss whether the calculated daily intakes are adequate.

\section{PATIENTS AND METHODS}

The study was carried out during 1985-6 in seven villages in Chandpur, $64 \mathrm{~km}$ south-east of Dhaka. $85 \%$ of the infants in these villages are breast-fed for $24-30$ months (Brown $e t$ al. 1982). Thirty-four mothers were randomly selected. Their mean height was 1.49 (SD 0.06$)$ $\mathrm{m}$. Their mean weight was 40.7 (SD 4.6 ) $\mathrm{kg}$ at 1 month and 39.2 (SD 4.8 ) $\mathrm{kg}$ at 12 months postpartum (73-76\% average ideal body-weight; Metropolitan Life Insurance Company, 1983). 
Table 1. Weights $(\mathrm{kg})$ of infants in Bangladesh

(Mean values and standard deviations; no. of infants in parentheses)

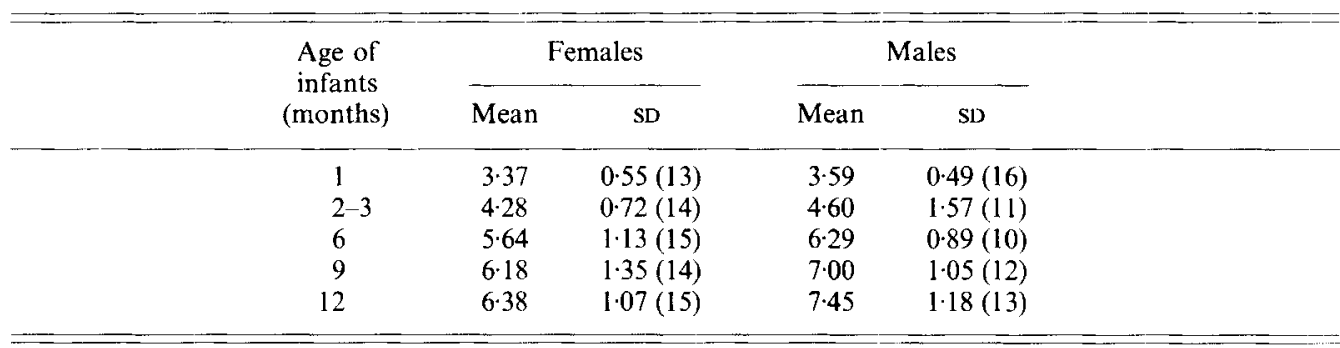

Bangladeshi health assistants visited the villages when the babies were 1, 2-3, 6, 9 and 12 months of age. The babies were weighed and breast milk collected between 10.00 and 14.00 hours from each breast at the beginning and end of feeds. Sample size varied due to cessation of breast-feeding associated with further pregnancies and occasionally due to unavailability of the mothers.

Breast milk was stored at $-20^{\circ}$. Samples of whole milk $(0.5-1.0 \mathrm{ml})$ were ashed in Pyrex beakers and then digested in $1.0 \mathrm{M}$-hydrochloric acid. All glassware and plastic test tubes were soaked in $10 \% \mathrm{HCl}$ for $24-48 \mathrm{~h}$ and then rinsed three times in deionized water. Concentrations of $\mathrm{Zn}$ and $\mathrm{Cu}$ were measured by atomic absorption spectrophotometry using an air acetylene flame (model 257; Instrumentation Laboratories, Cheshire). For analysis of $\mathrm{Zn}$ the spectrophotometer was operated at $213.9 \mathrm{~nm}$ and, for $\mathrm{Cu}$, at $324.7 \mathrm{~nm}$. Standards were diluted with $1.0 \mathrm{M}-\mathrm{HCl}$ (Aristar grade; British Drug Houses Chemicals Ltd, Poole, Dorset). Both internal and external standards (Nyegaard, Birmingham) were used with $98 \%$ agreement. The absorption of $1.0 \mathrm{M}-\mathrm{HCl}$ in the $\mathrm{Zn}$ and $\mathrm{Cu}$ wavelengths was negligible.

Trace element intakes were expressed as absolute intakes and as intakes per $\mathrm{kg}$ bodyweight. The daily intakes of $\mathrm{Zn}$ and $\mathrm{Cu}$ were calculated from the breast milk concentration and the expected volume produced. The volumes of breast milk measured by Brown et al. (1986) studying women from the same Bangladeshi villages were used. They admitted the mothers and infants to hospital wards for $2-3 \mathrm{~d}$ on several occasions. During the first $24 \mathrm{~h}$ of each visit, the women nursed their infants ad lib., and the amounts consumed were estimated by test weighings. During the second $24 \mathrm{~h}$, all milk was extracted from both breasts every $3 \mathrm{~h}$ using a mechanical breast pump. The next day test weighing was repeated.

Our study was approved by the ethical committee of the Bangladesh Research Council and informed consent was obtained from the mothers.

The results are expressed as means and standard deviations and were analysed by the unpaired Student's $t$ test.

\section{RESULTS}

Mean weights of the infants by sex are given in Table 1, and from 3 months of age (Fig. $1(a, b)$ ) fell below the third percentile for children in developed countries (Tanner \& Whitehouse, 1976).

Breast milk $\mathrm{Zn}$ concentration decreased with time, and significantly between 1 and 2 months $(P<0.025), 1$ and 6 months $(P<0.005)$ and between 6 and 12 months $(P<0.005)$. Mean daily $\mathrm{Zn}$ intake from breast milk fell from $17 \cdot 7 \mu \mathrm{mol}$ at 1 month to $8 \mu \mathrm{mol}$ at 9 months (10-30\% recommended dietary allowance (RDA); National Research Council, 1980) (Table 2). 

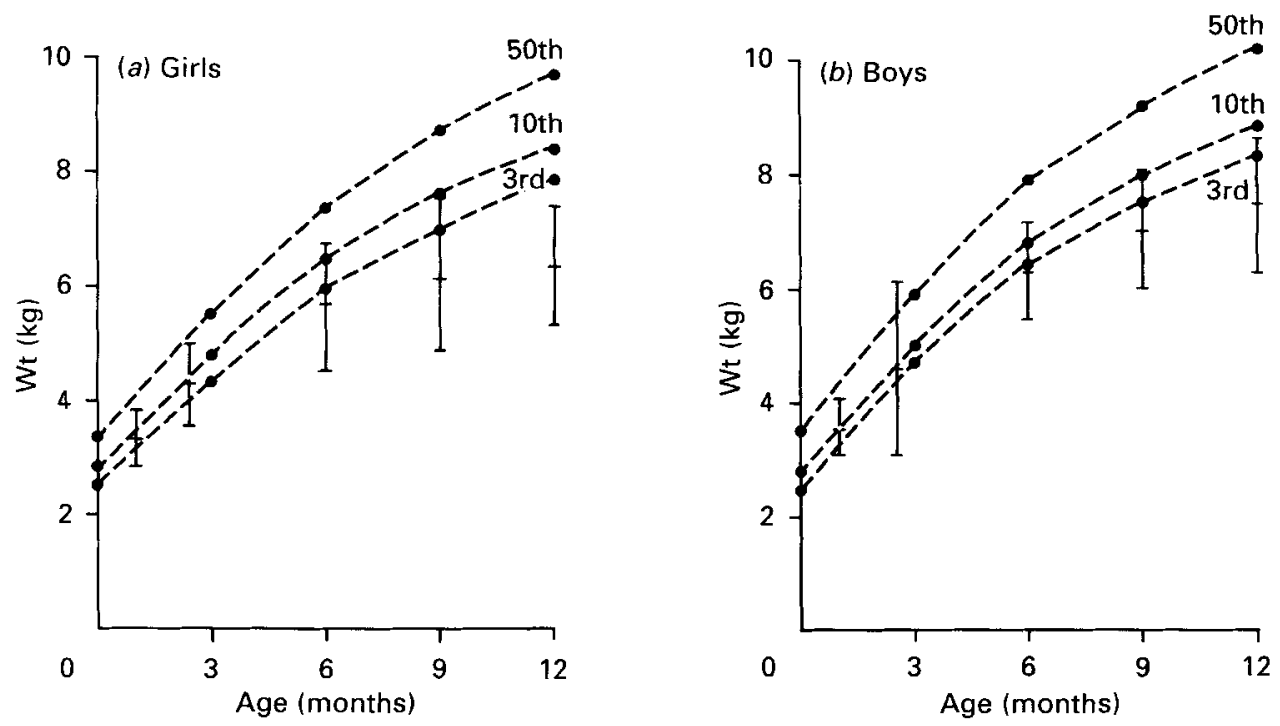

Fig. 1. Mean weights of Bangladeshi infants, $(a)$ male and $(b)$ female, compared with British standards (3rd, 10th and 50th percentiles, Tanner $\&$ Whitehouse, 1976). Values are means and standard deviations represented by the vertical bars.

Table 2. Zinc in breast milk of Bangladeshi mothers $\dagger$

(Mean values and standard deviations)

\begin{tabular}{|c|c|c|c|c|c|}
\hline \multirow{2}{*}{$\begin{array}{l}\text { Age of } \\
\text { infant } \\
\text { (months) }\end{array}$} & \multirow[b]{2}{*}{$n$} & \multicolumn{2}{|c|}{$\begin{array}{l}\text { Breast milk } \\
\mathrm{Zn}(\mu \mathrm{mol})\end{array}$} & \multicolumn{2}{|c|}{$\begin{array}{l}\text { Calculated breast } \\
\text { milk } \mathrm{Zn} \text { intake }\end{array}$} \\
\hline & & Mean & SD & per d & $\mu \mathrm{mol} / \mathrm{d}$ \\
\hline 1 & 31 & $30 \cdot 0$ & $15 \cdot 1$ & $5 \cdot 1$ & 17.7 \\
\hline $2-3$ & 11 & $19 \cdot 1^{*}$ & $8 \cdot 2$ & 2.8 & 12.9 \\
\hline 6 & 11 & $14 \cdot 2^{* *}$ & $6 \cdot 2$ & 1.8 & $10 \cdot 9$ \\
\hline 9 & 21 & $11 \cdot 1$ & $9 \cdot 4$ & $1 \cdot 2$ & 8.0 \\
\hline 12 & 30 & $8 \cdot 3^{* *}$ & $4 \cdot 2$ & - & - \\
\hline RDA & & & & & $46-77$ \\
\hline
\end{tabular}

RDA, recommended dietary allowances (National Academy of Sciences, 1980).

Mean values were significantly different: ${ }^{*} P<0 \cdot 025$, I month $v .2-3$ months; ${ }^{* *} P<0-005,1$ month $v .6$ months and 6 months $v .12$ months.

$\dagger$ For details of procedure, see pp. 91-92.

$\$$ Volumes (g/kg per d) : 1 month 168 (SD 30), n 36;2-3 months 149 (SD 29), $n 75 ; 6$ months 125 (SD 24), $n$ 13; 9 months 118 (SD 24), $n 5$ (Brown et al. 1986).

Breast milk $\mathrm{Cu}$ concentration decreased over the first 12 months $(P<0.005)$ and mean daily $\mathrm{Cu}$ intake from breast milk was $1.95-2.63 \mu \mathrm{mol}$ over the first 9 months (RDA 7.81-15.63 $\mu \mathrm{mol}$ ) (Table 3).

\section{DISCUSSION}

The adequacy of breast milk as the only source of infant nutrition is related to the mother's diet in pregnancy, physical and emotional stress, maternal and fetal protein and energy 


\section{Table 3. Copper in breast milk of Bangladeshi mothers $\dagger$}

(Mean values and standard deviations)

\begin{tabular}{|c|c|c|c|c|c|}
\hline \multirow{2}{*}{$\begin{array}{l}\text { Age of } \\
\text { infants } \\
\text { (months) }\end{array}$} & \multirow[b]{2}{*}{$n$} & \multicolumn{2}{|c|}{$\begin{array}{c}\text { Breast milk } \\
\mathrm{Cu}(\mu \mathrm{mol} / \mathrm{l})\end{array}$} & \multicolumn{2}{|c|}{$\begin{array}{l}\text { Calculated breast } \\
\text { milk Cu intake } \ddagger\end{array}$} \\
\hline & & Mean & SD & per d & $\mu \mathrm{mol} / \mathrm{d}$ \\
\hline 1 & 31 & 3.44 & 1.88 & 0.58 & 2.02 \\
\hline $2-3$ & 11 & 3.75 & 1.56 & 0.56 & 2.63 \\
\hline 6 & 11 & $2 \cdot 97$ & 1.09 & 0.38 & $2 \cdot 22$ \\
\hline 9 & 21 & $2 \cdot 50$ & 2.03 & $0 \cdot 30$ & 1.95 \\
\hline 12 & 30 & $1 \cdot 88^{*}$ & $1 \cdot 25$ & -- & - \\
\hline RDA & & & & & $7 \cdot 81-15 \cdot 63$ \\
\hline
\end{tabular}

RDA, recommended dietary allowances (National Academy of Sciences, 1980).

Mean value was significantly different: ${ }^{*} P<0.005,1$ month $v$. 12 months.

$\uparrow$ For details of procedures, see pp. 91.92.

\$ Volumes (g/kg per d): 1 month 168 (SD 30), $n$ 36;2-3 months 149 (SD 29), $n 75 ; 6$ months 125 (SD 24), $n$ 13; 9 months 118 (SD 24), $n 5$ (Brown et al. 1986).

Table 4. Breast milk zinc concentrations ( $\mu$ mol/l) of women from developed and developing countries

\begin{tabular}{|c|c|c|c|c|c|}
\hline $\begin{array}{c}\text { Age of infants (months)... } \\
\text { Source }\end{array}$ & $0 \cdot 5-1$ & $2-3$ & $5-6$ & 9 & 12 \\
\hline Simmer et al. (present study) & $30 \cdot 0$ & $19 \cdot 1$ & $14 \cdot 2$ & $11 \cdot 1$ & $8 \cdot 3$ \\
\hline Vuori \& Kuitunen (1979) & - & $20 \cdot 0$ & $7 \cdot 5$ & $7 \cdot 4$ & - \\
\hline Vuori et al. (1980) & - & $29 \cdot 1$ & $11 \cdot 1$ & - & - \\
\hline Belavady (1978) & - & $73 \cdot 2$ & $20 \cdot 8$ & $16 \cdot 0$ & - \\
\hline Shaw $(1980 a, b)$ & $52 \cdot 3$ & $29 \cdot 2$ & $12 \cdot 3$ & - & - \\
\hline Matsuda et al. (1984) & $44 \cdot 6$ & 16.9 & $16 \cdot 9$ & - & - \\
\hline Karra et al. (1986) & - & - & $14 \cdot 2$ & $12 \cdot 5$ & $10 \cdot 5$ \\
\hline Kirsten et al. (1985) & $35 \cdot 1$ & - & - & $10 \cdot 0$ & - \\
\hline
\end{tabular}

stores and birth weight. Our findings demonstrate that the mean weight of breast-fed infants in Bangladesh begins to fall from the normal Western range at 2-3 months, which is consistent with previous reports of Bangladeshi infants (Brown et al. 1986) and indicates that breast milk may not be nutritionally adequate for these infants.

Breast milk $\mathrm{Zn}$ concentrations fell significantly from 1 to 12 months and levels were consistent with those reported from developed and developing countries (Table 4). Karra et al. (1986) have suggested that the decline in $\mathrm{Zn}$ concentration may be due to gradual involution of the mammary gland from decreased frequency of breast-feeding, and a progressive alteration in the mechanism of $\mathrm{Zn}$ transport to breast milk, namely from transcellular to paracellular pathways and with less binding to ligands.

Daily $\mathrm{Zn}$ intake was as low as $10 \%$ of the RDA at 9 months. Despite the high bioavailability of $\mathrm{Zn}$ from breast milk (Casey et al. 1981), the $\mathrm{Zn}$ intake of Bangladeshi infants would fail to reach the relatively low estimate calculated by Krebs \& Hambidge (1986) to be essential for growth. We have previously shown that $\mathrm{Zn}$ depletion is an important factor limiting weight gain in children receiving nutritional rehabilitation in Bangladesh (Simmer et al. 1988). Similarly, Golden \& Golden (1981), found that the 
Table 5. Breast milk copper concentrations ( $\mu$ mol/l) of women from developed and developing countries

\begin{tabular}{|c|c|c|c|c|c|}
\hline $\begin{array}{l}\text { Age of infants (months) ... } \\
\text { Source }\end{array}$ & $0.5-1$ & $2-3$ & $5-6$ & 9 & 12 \\
\hline Simmer et al. (present study) & $3 \cdot 44$ & $3 \cdot 75$ & 2.97 & $2 \cdot 50$ & 1.88 \\
\hline Vuori \& Kuitunen (1979) & - & $5 \cdot 16$ & $2 \cdot 66$ & 3.91 & - \\
\hline Vuori et al. (1980) & - & 5.63 & $3 \cdot 28$ & - & - \\
\hline Belavady (1978) & - & $7 \cdot 50$ & $3 \cdot 28$ & $2 \cdot 66$ & - \\
\hline Shaw $(1980 a, b)$ & $7 \cdot 66$ & $8 \cdot 13$ & $4 \cdot 38$ & - & - \\
\hline Matsuda et al. (1984) & 6.94 & $4 \cdot 22$ & $3 \cdot 13$ & - & - \\
\hline Salmenpera et al. (1986) & - & 3.59 & $2 \cdot 34$ & $1 \cdot 56$ & $2 \cdot 19$ \\
\hline Kirsten et al. (1985) & - & - & - & $4 \cdot 38$ & - \\
\hline
\end{tabular}

Jamaican diet did not provide adequate $\mathrm{Zn}$ for weight gain in children recovering from marasmus. In addition, $\mathrm{Zn}$ deficiency may contribute to the diarrhoea, rash, infection and vitamin A deficiency in malnourished children.

The concentration of $\mathrm{Cu}$ in Bangladeshi breast milk was lower than that reported from developed countries (Table 5), except for a recent Finnish study (Salmenpera et al. 1986). The Cu concentration of breast milk collected in India was similar to that from Bangladesh from 4 months but higher before this age (Belavady, 1978). Daily $\mathrm{Cu}$ intake was less than $25 \%$ of the RDA. Cu deficiency in infancy has been associated with anaemia, oedema and bone disease (Al-Rashid \& Spangler, 1971; Levy et al. 1985; Sutton et al. 1985) and may well contribute to morbidity in Bangladeshi infants.

The daily $\mathrm{Zn}$ and $\mathrm{Cu}$ intakes from breast milk in Bangladesh were low mainly due to the low volume of milk produced. The volumes used in our calculations are consistent with, if not somewhat higher than, those measured in other developing countries (Jelliffe \& Jelliffe, 1978). Therefore, increasing the volume of milk produced would be the best way of improving $\mathrm{Zn}$ and $\mathrm{Cu}$ intakes of breast-fed infants in Bangladesh and limited studies of giving supplementary protein to poorly nourished mothers have suggested such an improvement (Jelliffe \& Jelliffe, 1978). Supplementing the mothers with $\mathrm{Zn}$ may decrease the abnormally steep decline in breast milk $\mathrm{Zn}$ concentrations (Krebs et al. 1985), whereas maternal $\mathrm{Cu}$ supplementation does not appear to influence breast milk $\mathrm{Cu}$ concentration (Salmenpera et al. 1986).

Alternatively, appropriate semi-solids could be introduced at 3-4 months. $\mathrm{Zn}$ is present in high concentrations in red meat, sea food and unprocessed cereals and nuts, and $\mathrm{Cu}$ in shellfish, liver and kidney. The weaning foods in these villages have been well documented and certainly, at present, would not supply enough $\mathrm{Zn}$ and $\mathrm{Cu}$ (e.g. $50 \%$ children by 30 months have never received meat, fish or eggs (Brown et al. 1982)).

In conclusion, dietary intakes of $\mathrm{Zn}$ and $\mathrm{Cu}$ are suboptimal in breast-fed Bangladeshi infants. Such deficiencies may contribute to their extremely poor growth. Trace element supplements are probably not feasible. Improving the mother's diet is the best solution, with education about the preparation and timing of weaning foods.

\section{REFERENCES}

Al-Rashid, A. A. \& Spangler, J. (1971). Neonatal copper deficiency. New England Journal of Medicine 285 , 841-843.

Belavady, B. (1978). Lipid and trace element composition of human milk. Acta Paediatrica Scandinavica 67, $566-571$. 
Brown, K. H., Back, R. E., Becker, S., Nahar, S. \& Sawyer, J. (1982). Consumption of foods and nutrients by weanlings in rural Bangladesh. American Journal of Clinical Nutrition 36, 878-889.

Brown, K. H., Robertson, A. D. \& Akhtar, N. A. (1986). Lactational capacity of marginally nourished mothers: infants' milk nutrient consumption and patterns of growth. Pediatrics 78, 920-927.

Casey, C. E., Walravens, P. A. \& Hambidge, K. M. (1981). Availability of zinc: loading tests with human milk, cows' milk and infant formula. Pediatrics 68, 394-396.

Golden, B. E. \& Golden, M. H. N. (198I). Trace elements - potential importance in human nutrition with particular reference to zinc and vanadium. British Medical Bulletin 37, 31-36.

Jelliffe, D. B. \& Jelliffe, E. F. P. (1978). The volume and composition of human milk in poorly nourished communities. A review. American Journal of Clinical Nutrition 31, 492-515.

Karra, M. V., Volipi, S. A., Kirksey, A. \& Roepke, J. L. B. (1986). Changes in specific nutrients in breastmilk during extended lactation. American Journal of Clinical Nutrition 43, 495-503.

Kirsten, G. F., Heese, H. D., Watermeyer,S., Dempster, W. S., Pocock, F. \& Varkevisser, H. (1985). Zinc and copper levels in breastmilk from Cape Town mothers. South African Medical Journal 68, 402-405.

Krebs, N. F., Hambidge, K. M., Jacobs, M. A. \& Rasbach, J. O. (1985). The effects of a dietary zinc supplement during lactation on maternal zine status and milk zinc concentrations. American Journal of Clinical Nutrition 41, 571-577.

Krebs, N. F. \& Hambidge, K. M. (1986). Zinc requirements and zinc intakes of breastfed infants. American Journal of Clinical Nutrition 43, 288-292.

Levy, Y., Zeharia, A., Grunebaum, M., Nitzan, M. \& Steinherz, R. (1985). Copper deficiency in infants fed cows milk. Journal of Pediatrics 106, 789-788.

Matsuda, I., Higashi, A., Ikeda, T., Uehara, I. \& Kuroki, Y. (1984). Effects of zinc and copper content of formulas on growth and on the concentrations of zinc and copper in serum and hair. Journal of Pediatric Gastroenterology and Nutrition 3, 421-425.

Metropolitan Life Insurance Company (1983). Metropolitan height and weight tables. Statistical Bulletin 64, $2-9$.

National Academy of Sciences (1980). Food and Nutrition Board Recommended Dietary Allowances, 9th ed. Washington, DC: National Academy of Sciences.

Salmenpera, L., Perheentupa, J., Pakarinen, P. \& Siimes, M. (1986). Copper nutrition in infants during prolonged exclusive breastfeeding: low intake but rising concentrations of copper and ceruloplasmin. American Joumal of Clinical Nutrition 43, 251-257.

Shaw, J. C. L. (1980a). Trace elements in the fetus and young infant. American Journal of Diseases in Childhood $133,12601268$.

Shaw, J. C. L. $(1980 \mathrm{~b})$. Trace elements in the fetus and young infant. American Journal of Diseases in Childhood 134, $74-81$.

Simmer, K., Khanum, S., Carlsson, L. \& Thompson,. R. P. H. (1988). Nutritional rehabilitation in Bangladesh - the importance of zinc. American Journal of Clinical Nutrition 47, 1036-1040.

Sutton, A. M., Harvie, A., Cockburn, F., Farquarson, J. \& Logan, R. W. (1985). Copper deficiency in the preterm infant of very low birthweight. Archives of Diseases in Childhood 60, 644651.

Tanner, J. W. \& Whitehouse, R. A. (1976). Clinical longitudinal standards for height, weight, height velocity and weight velocity and the stages of puberty. Archives of Diseases in Childhood 51, 170.

Vuori, E. \& Kuitunen, P. (1979). The concentration of copper and zinc in human milk. A longitudinal study. Acta Paediatrica Scandinavica 68, 33-37.

Vuori, E., Makinen, S. M., Kara, R. \& Kuitunen, P. (1980). The effects of the dietary intakes of copper, iron, manganese and zinc on the trace element content of human milk. American Journal of Clinical Nutrition 33, 227-231. 